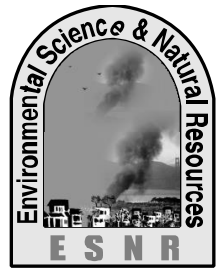

\title{
Efficacy of Amistar in Controlling Alternaria Blight and Yield of Mustard Variety Rai-5
}

\author{
I. Hossain*, M. A. Akter and M. B. Anwar
}

Department of Plant Pathology, Bangladesh Agricultural University,Mymensingh-2202, Bangladesh

*Corresponding author: dhossain69@gmail.com

\begin{abstract}
The effect of Amistar in controlling Alternaria blight of mustard was investigated and the selected mustard variety Rai5 was used. Amistar @ 0.05\% (1 spray), 0.05\% (2 spray), 0.05\% (3 spray), 0.1\% (1 spray), 0.1\% (2 spray) and 0.1\% (3 spray) were sprayed at 14 days interval beginning from 40 days after sowing (DAS). Amistar resulted significant reduction of the disease Alternaria blight (Alternaria brassicae and Alternaria brassicicola) severity and increased seed yield. Out of the doses of Amistar used, 0.1\% (3 spray) showed marked effect in reducing the disease over control in terms of reduction of $\%$ Alternaria blight incidence, $\%$ leaf infection and $\%$ leaf area diseased up to $90.72 \%, 90.42 \%$ and $98.17 \%$, respectively as well as reduction of $\%$ siliqua infection and $\%$ area of siliqua diseased up to $96.17 \%$ and $98.80 \%$, respectively and thus increased seed yield up to $56.47 \%$ over control.
\end{abstract}

Key words: Alternaria blight, Amistar, Mustard, Yield

\section{Introduction}

Mustard (Brassica juncea, B.campestris and B.napus) is an important oilseed crop in Bangladesh. The average yield of mustard in the country is only 1001 $\mathrm{kg} / \mathrm{ha}$ (BBS, 2008), which is low compared to many other mustard growing countries of the world (Ahmed et al., 1988). Many factors are associated with the poor yield of mustard in Bangladesh. Diseases have been identified as one of the major factors (Ahmed, 1992). Mustard suffers from at least 10 diseases in Bangladesh (Meah et al., 1985). Alternaria blight of mustard has been recognized as the most serious and devastating disease in this country (Khatun et al, 2011); this disease causes an average yield loss of 30$60 \%$ in Bangladesh (Meah et al., 1988). It can some extent be managed through the use of fungicides (Meah et al. 1988, Howlider et al. 1985). Multifarious efforts have been made worldwide to control the disease. There is no information available on the resistance source although some sort of tolerance to the disease has been reported (Rai et al., 1976). Chemicals have been successfully used in controlling the diseases (Meah et al., 1988; Howlider et al., 1985 and Kolte and Tewari, 1978). Amistar (azoxystrobin) is a class of fungicide having favorable environment profile and novel mode of action leading to a high efficacy against all major groups of plant pathogens under Ascomycetes, Basidiomycetes, Deuteromycetes and Oomcetes (Godet et al., 1997). Amistar has been reported to control fungal and bacterial infection in cabbage (Robak, 1998), oilseed rape (Weber and Karolewski, 2000), barley and cucumber (Timmer, 1999; Robak and Sobolewski, 1997) and in rice and chilli (Firoz and Hossain, 2000 and Rahman, 2002). As
Amistar have wide range of fungicidal action, therefore, the present research work was designed to achieve the following objectives: To find out the efficacy of Amistar in controlling Alternaria blight of mustard and to determine the effect of Amistar on yield of mustard.

\section{Materials and Methods}

The experiments were carried out in the Field Laboratory as well as in the Laboratory of Plant Pathology and Seed Pathology Center (SPC), Bangladesh Agricultural University (BAU), Mymensingh. The experiments were carriedout from November 2004 to April 2005. Seeds of mustard (Brassica campestris) variety Rai-5 were collected from Department of Genetics and Plant Breeding Bangladesh Agricultural University, Mymensingh. The experiment was in Completely Randomized Block Design (RCBD) with three replications. Amistar (azoxystrobin), a fungicide used in the experiment. The treatments were used in the experiment were $\mathrm{T} 1=$ Control (untreated), $\mathrm{T}_{2}=0.05 \%$ (Single spray), $\mathrm{T}_{3}=$ $0.05 \%$ (Double spray), $\mathrm{T}_{4}=0.05 \%$ (Triple spray) $\mathrm{T}_{5}=$

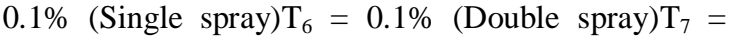
$0.1 \%$ (Triple spray). Data were collected on the following parameters: i) Plant infection (\%) ii) Leaf infection (\%), iii) Leaf area diseased (\%), iv) Siliqua infection (\%), v) Area of siliqua diseased (\%), vi) Plant height (cm), vii) Number of branches/plant, viii) Total number of seeds/plant, ix) Weight of seeds/plant (g), $\mathrm{x}$ ) Weight of seeds/plot (g) and $x i$ ) Seed yield/ha (t). Data on the first eight parameters were recorded before harvest. Progress in plant infection, leaf infection and leaf area diseased were monitored at 45 DAS, 60 DAS, 
and 75 DAS. Total siliqua infection and area of siliqua diseased were recorded at 70 DAS, 77 DAS, and 84 DAS. Plant height $(\mathrm{cm})$ and number of branches per plant were recorded at 90 DAS.

\section{Results and Discussion}

The crop was infected by Alternaria blight (Alternaria brassicae and Alternaria brassicicola) under natural condition (Fig. 4). Characteristics ring spots of the disease first appeared mostly on the older leaves at 40 days after sowing. Gradually, whole leaf area became covered with spots and the leaves turned yellow, blighted and defoliation occurred. Stem infection was characterized by elongated dark brown lesions. Later on, the siliqua was infected showing round to irregular dark brown spots. The cause of the Alternaria blight of mustard was identified as Alternaria brassicae (Beak.) Sacc. And Alternaria brassicicola (Schw.) Wiltshire. The fungi were identified by studying the morphological characters (Mathur and Kongsdal, 1994). The conidia of $A$. brassicae is straight, obclavate, rostrate with transverse and longitudinal of oblique septa, pale or grayish olive, smooth, long beak about $1 / 3$ to $1 / 2$ the length of the conidium. The conidia of $A$. brassicicola is straight, cylindrical (conical) usually tapering slightly towards the apex, basal cell rounded, mostly with transverse septa, pale to dark olivaceous brown and beak not visible or absent. The effect of Amistar on disease incidence (\%) of mustard variety Rai-5 was determined at 45, 60, 75 days after sowing (DAS). Data regarding the effect of
Amistar of the incidence of Alternaria blight of mustard are presented in Table 1. Amistar showed significant influence on Alternaria blight incidence (\%) at different days after sowing. The disease incidence $(\%)$ varied from $9.16 \%$ to $98.75 \%$ under different treatments, where the highest disease incidence was found in control plot (T1) and the lowest disease incidence was found in the plot treated with Amistar $0.1 \%$ (3 spray) which was statistically similar to Amistar $0.05 \%$ (3 spray) and Amistar 0.1\% (2 spray) at75 DAS. Different concentration of Amistar spray resulted profound effect in reducing \% leaf infection as shown in Table 2. Amistar showed significant influence on $\%$ leaf infection at different days after sowing. \% leaf infection was significantly different among the treatments. Percent leaf infection ranged from 6.76 to 70.53 , where the maximum $\%$ leaf infection was found in control plot (T1) and the minimum \% leaf infection was found in the plot treated with Amistar 0.1\% (3 spray) at 75 DAS. Percent leaf area diseased was found significantly different in different days after sowing, except 45 DAS. At 45 DAS, \% leaf area diseased ranged from 1.70 to 1.74 which was not significantly different from one to another (Table 3). At 75 DAS, the highest \% leaf area diseased was found in control plot (Ti) at 60 DAS and the lowest \% leaf area diseased was found in the plot treated with Amistar $0.1 \%$ (3 spray) which was statistically similar to Amistar $0.1 \%$ (2 spray) and Amistar $0.05 \%$ (3 spray) at 75 DAS.

Table 1. Effect of Amistar on disease incidence (\%) of mustard variety Rai-5 at different days after sowing (DAS)

\begin{tabular}{|l|c|c|c|}
\hline \multirow{2}{*}{ Treatments } & \multicolumn{3}{|c|}{ Disease incidence (\%) } \\
\cline { 2 - 4 } & $45 \mathrm{DAS}$ & $60 \mathrm{DAS}$ & $75 \mathrm{DAS}$ \\
\hline $\mathrm{T}_{1}=$ Control & $24.37 \mathrm{a}$ & $82.48 \mathrm{a}$ & $98.75 \mathrm{a}$ \\
\hline $\mathrm{T}_{2}=$ Amistar 0.05\% (1 spray) & $24.32 \mathrm{a}$ & $23.33 \mathrm{~b}$ & $40.92 \mathrm{~b}$ \\
\hline $\mathrm{T}_{3}=$ Amistar 0.05\% (2 spray) & $22.44 \mathrm{ab}$ & $19.11 \mathrm{bc}$ & $24.85 \mathrm{c}$ \\
\hline $\mathrm{T}_{4}=$ Amistar 0.05\% ( 3 spray) & $21.12 \mathrm{ab}$ & $15.81 \mathrm{bcd}$ & $12.30 \mathrm{~d}$ \\
\hline $\mathrm{T}_{5}=$ Amistar 0.1\% ( 1 spray) & $20.97 \mathrm{~b}$ & $18.34 \mathrm{bcd}$ & $24.15 \mathrm{c}$ \\
\hline $\mathrm{T}_{6}=$ Amistar 0.1\% (2 spray) & $16.32 \mathrm{c}$ & $11.41 \mathrm{~cd}$ & $9.77 \mathrm{~d}$ \\
\hline $\mathrm{T}_{7}=$ Amistar 0.1\% (3 spray) & $16.26 \mathrm{c}$ & $11.21 \mathrm{~d}$ & $9.16 \mathrm{~d}$ \\
\hline LSD (P>0.05) & 3.077 & 7.168 & 3.735 \\
\hline
\end{tabular}

$\mathrm{DAS}=$ Days after sowing

$\mathrm{T}_{1}=$ Control (untreated), $\mathrm{T}_{2}=0.05 \%$ (Single spray), $\mathrm{T}_{3}=0.05 \%$ (Double spray), $\mathrm{T}_{4}=0.05 \%$ (Triple spray), $\mathrm{T}_{5}=0.1 \%$ (Single spray), $\mathrm{T}_{6}=0.1 \%$ (Double spray), $\mathrm{T}_{7}=0.1 \%$ (Triple spray). 
Table 2. Effect of Amistar on \% leaf infection of mustard variety Rai- 5 at different days after sowing (DAS)

\begin{tabular}{|l|c|c|c|}
\hline \multirow{2}{*}{ Treatments } & \multicolumn{3}{c|}{$\%$ leaf infection } \\
\cline { 2 - 4 } & $45 \mathrm{DAS}$ & $60 \mathrm{DAS}$ & $75 \mathrm{DAS}$ \\
\hline $\mathrm{T}_{1}=$ Control & $26.97 \mathrm{a}$ & $47.20 \mathrm{a}$ & $31.45 \mathrm{c}$ \\
\hline $\mathrm{T}_{2}=$ Amistar 0.05\% (1 spray) & $20.70 \mathrm{bcd}$ & $15.03 \mathrm{bc}$ & $27.71 \mathrm{~d}$ \\
\hline $\mathrm{T}_{3}=$ Amistar 0.05\% (2 spray) & $22.82 \mathrm{abc}$ & $13.17 \mathrm{~cd}$ & $12.29 \mathrm{e}$ \\
\hline $\mathrm{T}_{4}=$ Amistar 0.05\% ( 3 spray) & $18.94 \mathrm{~cd}$ & $13.58 \mathrm{bc}$ & $42.28 \mathrm{~b}$ \\
\hline $\mathrm{T}_{5}=$ Amistar 0.1\% ( 1 spray) & $25.50 \mathrm{a}$ & $16.93 \mathrm{~b}$ & $9.76 \mathrm{e}$ \\
\hline $\mathrm{T}_{6}=$ Amistar 0.1\% (2 spray) & $24.01 \mathrm{ab}$ & $12.40 \mathrm{~cd}$ & $6.76 \mathrm{f}$ \\
\hline $\mathrm{T}_{7}=$ Amistar 0.1\% (3 spray) & $18.47 \mathrm{~d}$ & $9.92 \mathrm{~d}$ & 2.942 \\
\hline LSD (P> 0.05) & 3.979 & 3.383 & \\
\hline
\end{tabular}

DAS $=$ Days after sowing

$\mathrm{T}_{1}=$ Control (untreated), $\mathrm{T}_{2}=0.05 \%$ (Single spray), $\mathrm{T}_{3}=0.05 \%$ (Double spray), $\mathrm{T}_{4}=0.05 \%$ (Triple spray), $\mathrm{T}_{5}=0.1 \%$ (Single spray), $\mathrm{T}_{6}=0.1 \%$ (Double spray), $\mathrm{T}_{7}=0.1 \%$ (Triple spray).

Table 3. Effect of Amistar on $\%$ leaf area diseased of mustard variety Rai-5 at different days after sowing (DAS)

\begin{tabular}{|l|c|c|c|}
\hline \multirow{2}{*}{ Treatments } & \multicolumn{3}{|c|}{ \% leaf area diseased } \\
\cline { 2 - 4 } & 45 DAS & 60 DAS & $11.49 \mathrm{a}$ \\
\hline $\mathrm{T}_{1}=$ Control & 1.70 & $12.97 \mathrm{a}$ & $2.66 \mathrm{~b}$ \\
\hline $\mathrm{T} 2=$ Amistar 0.05\% (1 spray) & 1.57 & $1.53 \mathrm{~b}$ & $1.30 \mathrm{~d}$ \\
\hline $\mathrm{T} 3=$ Amistar 0.05\% (2 spray) & 1.59 & $0.39 \mathrm{c}$ & $0.42 \mathrm{e}$ \\
\hline $\mathrm{T} 4=$ Amistar 0.05\% ( 3 spray) & 1.50 & $0.47 \mathrm{c}$ & $2.00 \mathrm{c}$ \\
\hline T5 = Amistar 0.1\% ( 1 spray) & 1.82 & $1.68 \mathrm{~b}$ & $0.27 \mathrm{e}$ \\
\hline T6 = Amistar 0.1\% (2 spray) & 1.77 & $0.51 \mathrm{c}$ & $0.21 \mathrm{e}$ \\
\hline T7 = Amistar 0.1\% (3 spray) & 1.74 & $0.39 \mathrm{c}$ & 0.252 \\
\hline LSD (I) 0.05) & NS & 0.718 & \\
\hline
\end{tabular}

DAS $=$ Days after sowing NS= Not significant

$\mathrm{T}_{1}=$ Control (untreated), $\mathrm{T}_{2}=0.05 \%$ (Single spray), $\mathrm{T}_{3}=0.05 \%$ (Double spray), $\mathrm{T}_{4}=0.05 \%$ (Triple spray), $\mathrm{T}_{5}=0.1 \%$ (Single spray), $\mathrm{T}_{6}=0.1 \%$ (Double spray), $\mathrm{T}_{7}=0.1 \%$ (Triple spray).

The effects of different doses of Amistar on \% siliqua infection of mustard variety Rai-5 is given in Table 4. Wide variations in \% siliqua infection were observed amongst the different treatments of Amistar and the variations were found to be statistically significant. \% siliqua infection ranged from 2.44 to 63.67 , where the highest $\%$ siliqua infection was found in control plot $\left(\mathrm{T}_{1}\right)$ at $84 \mathrm{DAS}$, and the lowest $\%$ siliqua infection was found in the plot treated with Amistar0.1\% (3 spray) which was statistically similar to Amistar $0.1 \%$ (2 spray). The effect of Amistar on \% area of siliqua diseased of mustard variety Rai-5 at 70, 77 and 84 days after sowing (DAS) are presented in Table 5. Percent area of siliqua diseased was significantly different in different days after sowing. At 84 DAS, significantly highest $\%$ area of siliqua diseased was found in control plot $\left(\mathrm{T}_{1}\right)$ and the lowest $\%$ area of siliqua diseased was recorded in the plot treated with Amistar $0.1 \%$ (3 spray) which was statistically similar to Amistar 0.05 $\%$ (1 spray), Amistar 0.05\% (3 spray), Amistar 0.1\% (1 spray) and Amistar $0.1 \%$ (2 spray) at 70 DAS. The effect of Amistar on plant height, number of branches/plant and number of seeds/plant of mustard variety Rai-5 infected with Alternaria blight was recorded and results are shown in Table 6. Respective plant height of Amistar treated plants under field conditions varied from $107.30 \mathrm{~cm}$ to $120.00 \mathrm{~cm}$. The maximum plant height was found the plot treated with Amistar $0.1 \%$ (3 spray) and the minimum height was found in control plot $\left(\mathrm{T}_{1}\right)$. The number of branches/plant varied from $2.33 \mathrm{~cm}$ to $3.95 \mathrm{~cm}$, where the maximum number of branches/plant was recorded in the plot treated with Amistar $0.1 \%$ (3 spray) which was statistically similar to Amistar $0.1 \%$ (2 spray) and the minimum number of branches/plant was recorded in the control plot $\left(\mathrm{T}_{1}\right)$. The number of seeds/plant 
ranged from 520.00 to 985.10 , where the maximum number of seeds/plant was found in the plots treated with Amistar $0.1 \%$ (3 spray) and the minimum number of seeds/plant was recorded in the control plot $\left(\mathrm{T}_{1}\right)$. The effect of Amistar on weight of seeds/plant, weight of seeds/plot and seed yield/ha of mustard variety Rai5 was recorded and the results are presented in Table 7. Amistar spraying resulted significant effect on the yield of Rai-5. Weight of seeds/plant under different treatments ranged from $1.13 \mathrm{~g}$ to $2.35 \mathrm{~g}$, where the highest seed weight was obtained in the plot treated with Amistar $0.1 \%$ (3 spray) and the lowest seed weight was found in the control plot $\left(\mathrm{T}_{1}\right)$. Weight of seeds/plot under different treatments ranged from $340.30 \mathrm{~g}$ to $530.40 \mathrm{~g}$, while the maximum weight of seeds/plot was obtained from Amistar $0.1 \%$ (3 spray) and the minimum weight of seeds/plot recorded in the control plot $\left(\mathrm{T}_{1}\right)$. Seed yield/ha under different treatments ranged from $0.85 \mathrm{t}$ to $1.33 \mathrm{t}$, while the significantly highest seed yield/ha was obtained from the plots that received Amistar 0.1\% (3 spray) and the lowest seed yield/ha obtained from the control plot $\left(\mathrm{T}_{1}\right)$. Application of Amistar resulted an increase of up to $56.47 \%$ seed yield over the untreated control.

Table 4. Effect of Amistar on \% siliqua infection of mustard variety Rai-5 at different days after sowing (DAS)

\begin{tabular}{|l|c|c|c|}
\hline \multirow{2}{*}{ Treatments } & \multicolumn{2}{c|}{ \% siliqua infection } \\
\cline { 2 - 4 } & $70 \mathrm{DAS}$ & $77 \mathrm{DAS}$ & $84 \mathrm{DAS}$ \\
\hline $\mathrm{T}_{1}=$ Control & $15.59 \mathrm{a}$ & $30.01 \mathrm{a}$ & $63.67 \mathrm{a}$ \\
\hline $\mathrm{T}_{2}=$ Amistar 0.05\% (1 spray) & $2.89 \mathrm{bc}$ & $6.97 \mathrm{~b}$ & $6.96 \mathrm{c}$ \\
\hline $\mathrm{T}_{3}=$ Amistar 0.05\% (2 spray) & $3.42 \mathrm{~b}$ & $4.01 \mathrm{~d}$ & $3.80 \mathrm{~d}$ \\
\hline $\mathrm{T}_{4}=$ Amistar 0.05\% 3 spray) & $2.11 \mathrm{de}$ & $2.46 \mathrm{e}$ & $21.13 \mathrm{~b}$ \\
\hline $\mathrm{T}_{5}=$ Amistar 0.1\% (1 spray) & $2.34 \mathrm{~cd}$ & $5.20 \mathrm{c}$ & $3.04 \mathrm{~d}$ \\
\hline $\mathrm{T}_{6}=$ Amistar 0.1\% (2 spray) & $1.54 \mathrm{ef}$ & $1.87 \mathrm{e}$ & $2.44 \mathrm{~d}$ \\
\hline $\mathrm{T}_{7}=$ Amistar 0.1\% (3 spray) & $\mathbf{1 . 1 4 f}$ & $1.53 \mathrm{e}$ & 1.805 \\
\hline LSD (P> 0.05) & 0.626 & 0.998 & \\
\hline
\end{tabular}

DAS $=$ Days after sowing

$\mathrm{T}_{1}=$ Control (untreated), $\mathrm{T}_{2}=0.05 \%$ (Single spray), $\mathrm{T}_{3}=0.05 \%$ (Double spray), $\mathrm{T}_{4}=0.05 \%$ (Triple spray), $\mathrm{T}_{5}=0.1 \%$ (Single spray), $\mathrm{T}_{6}=0.1 \%$ (Double spray), $\mathrm{T}_{7}=0.1 \%$ (Triple spray).

Table 5. Effect of Amistar on \% area of siliqua diseased of mustard variety Rai-5 at different days after sowing (DAS)

\begin{tabular}{|l|c|c|c|}
\hline \multirow{2}{*}{} & \multicolumn{2}{|c|}{ \% area of siliqua diseased } \\
\cline { 2 - 4 } & $70 \mathrm{DAS}$ & $77 \mathrm{DAS}$ & 84 DAS \\
\hline $\mathrm{T}_{1}=$ Control & $0.16 \mathrm{~b}$ & $0.38 \mathrm{a}$ & $0.67 \mathrm{a}$ \\
\hline $\mathrm{T}_{2}=$ Amistar 0.05\% (1 spray) & $0.023 \mathrm{c}$ & $0.08 \mathrm{~b}$ & $0.35 \mathrm{~b}$ \\
\hline $\mathrm{T}_{3}=$ Amistar 0.05\% (2 spray) & $0.22 \mathrm{a}$ & $0.04 \mathrm{~cd}$ & $0.05 \mathrm{c}$ \\
\hline $\mathrm{T}_{4}=$ Amistar 0.05\% ( 3 spray) & $0.02 \mathrm{c}$ & $0.03 \mathrm{dc}$ & $0.39 \mathrm{~b}$ \\
\hline $\mathrm{T}_{5}=$ Amistar 0.1\% ( 1 spray) & $0.02 \mathrm{c}$ & $0.06 \mathrm{c}$ & $0.04 \mathrm{c}$ \\
\hline $\mathrm{T}_{6}=$ Amistar 0.1\% (2 spray) & $0.02 \mathrm{c}$ & $0.02 \mathrm{e}$ & $0.02 \mathrm{c}$ \\
\hline $\mathrm{T}_{7}=$ Amistar 0.1\% (3 spray) & $0.01 \mathrm{c}$ & $0.02 \mathrm{e}$ & 0.1949 \\
\hline LSD (P> 0.05) & 0.01779 & 0.01779 & \\
\hline
\end{tabular}

DAS= Days after sowing

$\mathrm{T}_{1}=$ Control (untreated), $\mathrm{T}_{2}=0.05 \%$ (Single spray), $\mathrm{T}_{3}=0.05 \%$ (Double spray), $\mathrm{T}_{4}=0.05 \%$ (Triple spray), $\mathrm{T}_{5}=0.1 \%$ (Single spray), $\mathrm{T}_{6}=0.1 \%$ (Double spray), $\mathrm{T}_{7}=0.1 \%$ (Triple spray).

Table 6. Effect of Amistar on plant height (cm), number of branches/ plant and number of seeds/plant of mustard variety Rai-5 infected with Alternaria blight

\begin{tabular}{|l|c|c|c|}
\hline \multicolumn{1}{|c|}{ Treatments } & $\begin{array}{c}\text { Plant height } \\
(\mathrm{cm})\end{array}$ & $\begin{array}{c}\text { Number of } \\
\text { branches/plant }\end{array}$ & $\begin{array}{c}\text { Number of } \\
\text { seeds/plant }\end{array}$ \\
\hline $\mathrm{T}_{1}=$ Control & $107.30 \mathrm{c}$ & $2.33 \mathrm{c}$ & $520.00 \mathrm{~g}$ \\
\hline $\mathrm{T}_{2}=$ Amistar $0.05 \%$ (1 spray) & $111.70 \mathrm{bc}$ & $2.98 \mathrm{ab}$ & $545.00 \mathrm{f}$ \\
\hline $\mathrm{T}_{3}=$ Amistar $0.05 \%$ (2 spray) & $112.10 \mathrm{bc}$ & $2.99 \mathrm{ab}$ & $583.00 \mathrm{e}$ \\
\hline $\mathrm{T}_{4}=$ Amistar $0.05 \%$ (3 spray) & 114.406 & $3.60 \mathrm{ab}$ & $798.20 \mathrm{c}$ \\
\hline
\end{tabular}




\begin{tabular}{|l|c|c|c|}
\hline $\mathrm{T}_{5}=$ Amistar 0.1\% (1 spray) & $113.90 \mathrm{~b}$ & $2.70 \mathrm{bc}$ & $611.50 \mathrm{~d}$ \\
\hline $\mathrm{T}_{6}=$ Amistar 0.1\% (2 spray) & $117.00 \mathrm{ab}$ & $3.80 \mathrm{a}$ & 897.806 \\
\hline $\mathrm{T}_{7}=$ Amistar 0.1\% ( 3 spray) & $120.00 \mathrm{a}$ & $3.95 \mathrm{a}$ & $985.10 \mathrm{a}$ \\
\hline LSD $(\mathrm{p} ?$ ? 0.05) & 5.357 & 0.252 & 16.13 \\
\hline
\end{tabular}

DAS = Days after sowing

$\mathrm{T}_{1}=$ Control (untreated), $\mathrm{T}_{2}=0.05 \%$ (Single spray), $\mathrm{T}_{3}=0.05 \%$ (Double spray), $\mathrm{T}_{4}=0.05 \%$ (Triple spray), $\mathrm{T}_{5}=0.1 \%$

(Single spray), $\mathrm{T}_{6}=0.1 \%$ (Double spray), $\mathrm{T}_{7}=0.1 \%$ (Triple spray).

Table 7. Effect of Amistar on weight of seeds/plant (g), weight of seeds/plot ( $\mathrm{g}$ ) and seed yield (t/ha) of mustard variety Rai-5

\begin{tabular}{|l|c|c|c|}
\hline \multicolumn{1}{|c|}{ Treatments } & $\begin{array}{c}\text { Weight of } \\
\text { seeds/plant } \\
(\mathrm{g})\end{array}$ & $\begin{array}{c}\text { Weight of } \\
\text { seeds/plot } \\
(\mathrm{g})\end{array}$ & $\begin{array}{c}\text { Seed yield } \\
(\mathrm{t} / \mathrm{ha})\end{array}$ \\
\hline $\mathrm{T}_{1}=$ Control & $1.13 \mathrm{e}$ & $340.30 \mathrm{e}$ & $0.85 \mathrm{e}$ \\
\hline $\mathrm{T}_{2}=$ Amistar 0.05\% $(1$ & $1.23 \mathrm{de}$ & $390.20 \mathrm{~d}$ & $0.97 \mathrm{~d}(+14.12)$ \\
\hline $\mathrm{T}_{3}=$ Amistar 0.05\% $(2$ & $151 \mathrm{c}$ & $439.60 \mathrm{c}$ & $1.10 \mathrm{c}(+29.41)$ \\
\hline $1^{\prime}{ }_{4}=$ Amistar 0.05\% $(3$ & $1.96 \mathrm{~b}$ & $470.50 \mathrm{~b}$ & $1.18 \mathrm{~b}(+38.82)$ \\
\hline $\mathrm{T}_{5}=$ Amistar 0.1\% $(1$ & $1.44 \mathrm{~cd}$ & $402.40 \mathrm{~d}$ & $1.01 \mathrm{~d}(+18.82)$ \\
\hline $\mathrm{T}_{6}=$ Amistar 0.1\% $(2$ & 2.026 & $480.00 \mathrm{~b}(+41.18)$ \\
\hline $\mathrm{T}_{7}=$ Amistar 0.1\% $(3$ & $2.35 \mathrm{a}$ & $530.40 \mathrm{a}$ & $1.33 \mathrm{a}(+56.47)$ \\
\hline LSD $(13 ? 0.05)$ & 0.2516 & 13.69 & 0.0563 \\
\hline
\end{tabular}

$(+)=$ Percent yield increase over control

$\mathrm{T}_{1}=$ Control (untreated), $\mathrm{T}_{2}=0.05 \%$ (Single spray), $\mathrm{T}_{3}=0.05 \%$ (Double spray), $\mathrm{T}_{4}=0.05 \%$ (Triple spray), $\mathrm{T}_{5}=0.1 \%$

(Single spray), $\mathrm{T}_{6}=0.1 \%$ (Double spray), $\mathrm{T}_{7}=0.1 \%$ (Triple spray).

Altogether six spray doses and frequency were used such as: Amistar @ 0.05\% (1 spray), Amistar @ 0.05\% (2 spray), Amistar @ 0.05\% (3 spray), Amistar @ 0.1\% (1 spray), Amistar @ 0.1\% (2 spray) and Amistar@0.1\% (3 spray). From the results it was observed that Amistar $0.1 \%$ (3 spray) was more effective in reducing the incidence of leaf infection compared to the untreated control plants. Amistar $0.1 \%$ (3 spray) was better in reducing the disease compared to other treatments with the increasing age of the plants in the variety Rai-5. Amistar $0.05 \%$ (3 spray) was also effective but its effect was not as good as Amistar $0.1 \%$ (3 spray). At 75 DAS, remarkable effect was recorded with Amistar 0.1\% (3 spray) on reduction of disease incidence and severity over control. This is in accordance with the findings of Weber and Karolewski (2002). They reported that in Autumn application of Amistar $250 \mathrm{SC}$ on oil seed rape cultivars (Mar and Siliva) at 4-6 leaf stage and flowering stage resulted often more efficiently control of light blight spot on Mat, while Mejia and Hernandez (2001) supported that azoxystrobin at 100 and $200 \mathrm{~g}$ ai/ha gave only 3 to $5 \%$ disease incidence in leaves. Sidlauskiene et al. (2003) investigated the effects of different methods of controlling Alternaria leaf spot (Alternaria spp.) in cabbage, tomato and cucumber and reported that Amistar was the most effective among the fungicides which reduced disease incidence by $88.3-93.3 \%$. Ansari et al. (2004) reported that Amistar @ 0.1\% (2 spray) showed marked effect in reducing the Alternaria blight of mustard over control and increased $43.48 \%$ yield over control. Siliquae are important component of yield of mustard. It is fact that infection in siliqua greatly affects seed yield. The results of the present study have revealed that Amistar $0.1 \%$ (3 spray) is more effective in reducing the disease intensity on siliqua compared to control plots. Amistar 0.05\% (3 spray) was also effective but its effects were not as good as Amistar 0.1\% (3 spray). Mejia-Arreaza and Hernandez (2001) compared the efficacy of azoxystrobin with mancozeb and reported that azoxytrobin at 100 and 200 a.i./ha gave $2.5-3 \%$ disease incidence in fruits, whereas mancozeb at same rates registered 30 to $57 \%$ disease incidence. Though the intensity of siliqua infection was gradually increased with the age of the plants but the effect of Amistar was better to decrease the siliqua infection over control. Minimum disease intensity and maximum seed yields were obtained from Amistar 0.1\% (3 spray) treated plants than other treatments which indicate a 
tremendous influence of sprays of Amistar over Alternaria blight severity and maximizing seed yield. Amistar significantly increased plant height and number of branches/plant of mustard variety Rai-5 than that of control. Amistar 0.1\% (3 spray) was found more effective in increasing plant height and branches/plant than any other dose and significantly increased number of seeds/plant. The findings of the present study showed that Amistar has a significant effect on yield of mustard. Amistar resulted an increase in weight of seed/plant, weight of seeds/plot and seed yield/ha of mustard. Amistar $0.1 \%$ (3 spray) showed the best effect and increased seed yield by $56.47 \%$ over control. This result is strongly supported by Ansari et al. (2004). Amistar was found to show positive influence increasing yield which has been reported by Jensen (1999); Hossain (2002); Bayles (2000) and Zahradnicek and Svachula (2002). They reported that this product was highly potential in arresting the pathogenesis of a wide range of fungi including Alternaria spp.

\section{Conclusions}

According to the findings of the present study as well as the published research reports of the other workers it has been confirmed that Amistar has the strong potentiality of controlling Alternaria blight of mustard with subsequent increase of yield. Amistar can successfully be used for controlling Alternaria blight of mustard in Bangladesh.

\section{References}

Ahmed, H.V. 1992. Diseases of oil seed crops in Bangladesh. Lead paper presented in the 2nd Biennial Conference of the Bangladesh Phytopathological Society, held in 1992. Gazipur.p. 9.

Ahmed, M.S., M. Elias and J. Ahmed. 1988. Results of farm level socio-economic study on mustard production. Bangladesh Journal of Agricultural Research, 13 20-23.

Ansari, A.M., Monjil, M.S. and Hossain, I. 2004.Effecacy of Bion and Amistar in controlling Alternaria blight and yield of mustard variety Agrani. Journal of Bangladesh Agricultural University 2 1-8.

Bayles, R.A. 2000. The response of spring barley varieties to strobilurin fungicides. HGCA Project Report, 23782.

BBS. 2008. Year Book of Agricultural Statistics of Bangladesh. Bangladesh Bureau of Statistics. Ministry of Planning. Govt. of the Peopleôs Republic of Bangladesh, Dhaka. 134p.

Firoz, M. J. and Hossain, I. 2000. Induction of resistance to rice against some major diseases with increasing grain yield. Bangladesh Journal of Seed Science \& Technology, 4 3740.

Godet, F., Rogues, J. F. and Compagnon, J.M. 1997.Azoxystrobin: polyvalent cereal and grapevine fungicide. Phytoma. 50 52-54.

Howlider, M. A. R., Meah, M.B., Jalal uddin, M. and Rahman, A. 1985.Effect of fungicides in reducing intensity of Alternaria blight of mustard. Bangladesh Journal of Agricultural University, 10 41-46.

Jensen, E. K. 1999. Grain quality in relation to fungicide treatment of cereals, 16th Danish Plant Pretection Conference.Crop protection in organic farming Pest and Diseases. DJF Rapport Markburg 10 187-195.

Khatun, F., Alam, M.S. and Hossain, M.A. 2011. Effect of sowing dates and varieties on the severity of Alternaria blight of mustard. Bangladesh Journal of Agricultural Research, 36 583-594.

Kolte, S. J. and Tewari, A. N. 1978.Efficacy of certain chemicals for the control of Alternaria blight of yellow sarson.Dept. Plant Pathol. G. B. Plant. Univ. Agril. Technol. Pantanagar (Nanital). UP. India. 3181.

Kurolewski, T. P., Adamiak, E. and Balicki, T. 2002. The influence of fungicide Amistar $250 \mathrm{SC}$ on decrease of disease intensity and increase yield of spring barley cultivated in monoculture. Progress in Plant Protection 42 924-926.

Meah, M. B., Howlider, M. A. R. and Alam, K. 1985. Diseases of mustard and their control. Department of Plant Pathology, Bangladesh Agricultural University, Mymensingh. p. 12.

Meah, M. B., Howlider, M. A. R., Jalal uddin, M. and Rahman, A. 1988. Effect of fungicide spray at different time and frequencies on Alternaria blight of Mustard.Thai Jurnal of Agricultural Science, 21 101-107.

Mejia-Arreaza, J. and Hernandez, L. M. M. 2001.Evaluation of azoxystrobin on the early blight control (Alternaria solani) in tomatoes.Revista de la Facultad de Agronomia, Unviersidaddel Zulia 18 106-416.

Rahman, M. K. 2002. Induction of resistance against Anthracnose of chilli. M.S. Thesis, Dept. Plant Pathology, Bangladesh Agricultural University, Mymensingh, Bangladesh. p.72.

Rai, B., Kolte, S. J. and Tewari, A. N. 1976. Evaluation of Oleiferous brassicae germplasm for resistance to Alternaria leaf blight. Indian Phytopathology 29 76-77. 
Robak, J. 1998. Recent advance at integrated protection of cabbages against diseases with attention to club rot (plasmodiophora brassicae), Alternaria leaf spot (Alternaria spp.) and grey mold (Botrytis cinerea). Progress in Plant Protection 38 119-123.

Robak, J. and Sobolewski, J. 1997. New fungicides and possibility for their use in complex diseases control on vegetables. Progress in Plant Protection 37 350-353.

Sidlauskiene, A., Rasinskiene, A. and Surviliene, E. 2003. Effect of various protection means on Alternaria diseases of tomato, cucumber and cabbage seed plants. Sodininkyste it Darzininkyste 22 388-394.

Timmer, R. D. 1999. Control net blotch in summer barley by disinfecting seeds and spraying at the right time. PAV Bulletin Akkerbouw. Februari. Pp. 37-39.

Weber, Z. and Karolewski, Z. 2000. Influence of fungicide application in winter oilseed rape control against light leaf spot (Pyrnopeziza brassicae Suttonet Rawlinson). RoslinyOleiste 21 97-104.

Zahradnicek, J. and Svachula, V. 2002.Amistar and its effects on sugarbeet yield and quality parameters. Listy Cukrovarnicke a Reparske 118 134-135. 